\title{
Absorption, Distribution and Excretion of SM-10888 in Rats
}

\author{
Masashi Yabuki, Kazuhiko Iba, Iwao Nakatsuka and Akira Yoshitake \\ Environmental Health Science Laboratory, Sumitomo Chemical Co., Ltd. \\ 1-98, 3-Chome, Kasugade-Naka, Konohana-ku, Osaka, 554, Japan
}

Key words : SM-10888/tacrine/senile dementia of Alzheimer type/rats/disposition

\section{Summary}

9-Amino-8-fluoro-1, 2, 3, 4-tetrahydro-2, 4-methanoacridine citrate (SM-10888) was given to rats orally or intravenously, and its absorption, distribution and
\end{abstract} excretion were investigated.

1. After a single oral administration of ${ }^{14} \mathrm{C}-\mathrm{SM}-10888(5 \mathrm{mg} / \mathrm{kg})$, the serum

${ }^{14} \mathrm{C}$ level reached a maximum at $30 \mathrm{~min}(1.09 \mu \mathrm{g}$ eq. $/ \mathrm{g})$, with an $\mathrm{AUC}$ value corresponding to about $90 \%$ of that observed after intravenous administration, clearly revealing rapid and efficient absorption from the gastrointestinal tract.

Under fasted conditions, $C_{\max }$ was 2 -fold higher than that of non-fasted animals, without significant change in AUC, suggesting that diet causes delayed absorption. Both $\mathrm{C}_{\max }$ and AUC increased as the dose was raised from 1 to $20 \mathrm{mg} / \mathrm{kg}$. Repeated dosing $(5 \mathrm{mg} / \mathrm{kg} /$ day for 14 days) exerted little effect on serum ${ }^{14} \mathrm{C}$ levels.

2. After a single oral administration of ${ }^{14} \mathrm{C}-\mathrm{SM}-10888(5 \mathrm{mg} / \mathrm{kg})$, the radioactivity was distributed throughout the body, with relatively higher activities being observed in the digestive tract, the liver and the salivary gland. Radioactivity in each tissue had drastically decreased by $24 \mathrm{hr}$ post administration.

3. After a single oral administration of ${ }^{14} \mathrm{C}-\mathrm{SM}-10888(5 \mathrm{mg} / \mathrm{kg})$, cumulative excretion into the urine and feces after $168 \mathrm{hr}$ was $52.2 \%$ and $44.2 \%$, respectively. When administered to bile-duct cannulated rats, cumulative excretion after $72 \mathrm{hr}$ into the bile and urine was $65.1 \%$ and $29.1 \%$, respectively, providing further support for a high absorption rate.

Repeated dosing had little effect on the patterns of excretion into the urine and feces. 


\section{Introduction}

9-Amino-8-fluoro-1, 2, 3, 4-tetrahydro-2,4-methanoacridine citrate (SM-10888) is a potent cholinesterase inhibitor, which is being developed as a promising drug for treatment of senile dementia of the Alzheimer type (SDAT). It has been reported that SDAT is related to a specific deficit of central cholinergic function ${ }^{1,2)}$ and when tacrine, a cholinesterase inhibitor, was applied to patients with SDAT, significant improvements were recorded ${ }^{3,4)}$. SM-10888, a derivative of tacrine, was reported to have more desirable characteristics from animal studies in which it induced central cholinergic effects ${ }^{5)}$ and improved cognitive functions ${ }^{6)}$ at doses not causing any peripheral side effects.

In the present paper, the disposition of SM-10888 in rats is described.

\section{Materials and methods}

\section{Materials}

SM-10888 (Lot No. H-71) was synthesized by Sumitomo Pharmaceuticals Co., Ltd. Radiolabeled compound ${ }^{14} \mathrm{C}-\mathrm{SM}-10888$, Lot No. C-88-054) (Fig. 1) was synthesized by Sumitomo Chemical Co., Ltd. Radiochemical purity determined by thin layer chromatography (TLC) and high performance liquid chromatography (HPLC) was over 99\%. Chemical purity by HPLC was over $99 \%$. Specific activity was $0.80 \mathrm{GBq} / \mathrm{mmol}(2.14$ $\mathrm{MBq} / \mathrm{mg})$.

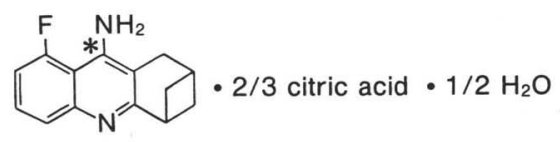

Fig. 1 Chemical structure of ${ }^{14} \mathrm{C}-\mathrm{SM}-10888$

(* : labeled position)

\section{Animals}

Seven-week old male Sprague-Dawley rats (Charles River Japan) weighing 254-319 g were used.

After purchase as six week olds, animals were given diet (CE-2, Clea Japan) and water ad libitum, and housed in a temperature $\left(23 \pm 2{ }^{\circ} \mathrm{C}\right)$, and humidity $(55 \pm 10 \%)$-controlled environment with a $12 \mathrm{hr}$ light-dark (light: $8: 00-20: 00$ ) cycle. Animals were housed for one week, and those without any abnormalities were submitted for experiments.

\section{Administration of Drugs}

${ }^{14} \mathrm{C}-\mathrm{SM}-10888$ was mixed with unlabeled SM-10888 and given to rats as a distilled water solution for oral dosing, and as a saline solution for intravenous dosing. Drug was administered to the animals under non-fasted conditions, except where otherwise stated.

\section{Oral administration}

Drug solution was given to rats orally at dose of $5 \mathrm{mg} / 10 \mathrm{ml} / \mathrm{kg}$ using gavage needles. 
To evaluate the effects of food on absorption, one group of rats were fasted for $24 \mathrm{hr}$ before dosing and refed starting $24 \mathrm{hr}$ after the administration. For the dose response study, 1 and $20 \mathrm{mg} / 10 \mathrm{ml} / \mathrm{kg}$ of dose were additionally given. The influence of repeated oral dosing was investigated using daily dose of $5 \mathrm{mg} / 10 \mathrm{~m} l / \mathrm{kg}$ for 14 days.

\section{Intravenous administration}

Saline solution was injected into the femoral veins of rats at dose of $5 \mathrm{mg} / \mathrm{ml} / \mathrm{kg}$ using disposable needles.

\section{Sampling}

\section{Serum}

After the drug administration, rats were housed in standard cages (Immortal ${ }^{\circledR}$, Okazaki Sangyo, Japan) and at the scheduled times, were anesthetized with ether (Kanto Chemical, Japan) to allow blood samples (ca. $0.3 \mathrm{~m} l$ at each point) to be collected via the retroorbital plexus. These were subsequently centrifuged $\left(3,000 \mathrm{rpm}, 10 \mathrm{~min}, 4{ }^{\circ} \mathrm{C}\right)$ to obtain serum samples.

Blood collections were conducted at the following time point : single dose : $5 \mathrm{~min}$ (only i.v. study), 15, 30min, 1, 2, 4, 6, 24, 48 and $72 \mathrm{hr}$. repeated dose : 15, 30min, 1, 2, 4, 6 and 24hr (days 1 and 14), 30min and 24hr (days 2 $-13)$

\section{Tissue}

After the drug administration, rats were housed in standard cages (Immortal ${ }^{\circledR}$, Okazaki Sangyo, Japan) and after 30min, 2hr, $24 \mathrm{hr}$ and $72 \mathrm{hr} *$, groups of animals were killed by exsanguination from the vena cava under ether anesthesia. The following tissues were then excised and washed with saline : cerebrum, cerebellum, pituitary*, salivary gland, thymus, heart, lung, liver, stomach, large intestine, small intestine, pancreas, spleen, adrenal, kidney, bladder, prostate*, testis, bone marrow, fat, muscle and skin.

(* : repeated dosing study only)

\section{Urine and Feces}

After the drug administration, rats were housed individually in metabolic cages (Metabolica ${ }^{\circledR}$, Sugiyamagen Iriki, Japan), and at the scheduled times, accumulated urine and feces were collected separately. Urine samples were applied directly to radioactivity measurement. Feces samples were mixed with $5 \%$ carboxymethyl cellulose (Kanto Chemical, Japan) solution, and then applied to radioactivity measurement.

Collection time points were as follows:

Single dose : 6, 24, 48, 72, 120 and $168 \mathrm{hr}$.

Repeated dose : 6 and 24hr (day 1), 24hr (days 2-13), 6, 24, 48 and 72hr (day 14).

\section{Bile}

The bile-ducts were first cannulated with polyethylens tubes ( $\mathrm{PE}-10$, Clay Adams, USA). After single oral administration, rats were kept in Bollman cages (KN-326, Nat- 
sume, Japan) and electrolytes (Solita-T3, Shimizu Pharmaceuticals, Japan) were given. Accumulated bile, urine and feces were collected separately at 6, 24, 48 and $72 \mathrm{hr}$.

\section{Determination of Radioactivity}

$0.1 \mathrm{~m} l$ aliquots of serum were mixed with $\mathrm{NCS}^{\circledR}$ (Amersham, USA), then $15 \mathrm{~m} l$ of TO LUENE SCINTILLATOR ${ }^{\circledR}$ (Pancard, USA) was added. Aliquots of tissue and feces samples (ca. 0.2 g) were combusted with a sample oxidizer (306, Packard, USA). Aliquots of urine and bile (ca. $0.2 \mathrm{~m} l$ ) were mixed with EMULSIFIER SCINTILLATOR ${ }^{\circledR}$ (Packard, USA). The radioactivities of all samples were determined using a liquid scintillation spectrometer (TRI-CARB 4640, Packard, USA).

\section{Results}

\section{Serum Radioactivity Level}

\section{Single Dose}

Serum levels of radioactivity after single oral or intravenous administration of ${ }^{14} \mathrm{C}-\mathrm{SM}-$ $10888(5 \mathrm{mg} / \mathrm{kg})$ under non-fasted conditions are shown in Fig. 2. Following oral administration, the level reached a maximum $\left(\mathrm{C}_{\max } 1.09 \mu \mathrm{g} \mathrm{eq} . / \mathrm{ml}\right)$ at $30 \mathrm{~min}$, and thereafter declined with a half-life of $\mathrm{ca}$. $10 \mathrm{hr}$. The $\mathrm{AUC}_{0-72}$ (calculated with trapezoidal rule, same hereafter) was $18.6 \mu \mathrm{g} \mathrm{eq} . \mathrm{hr} / \mathrm{ml}$. After intravenous administration, the serum level was $5.50 \mu \mathrm{g}$ eq. $/ \mathrm{ml}$ at $5 \mathrm{~min}$, followed by a biphasic decline with half-lives of ca. $3 \mathrm{hr}$ (to $24 \mathrm{hr}$ ) and ca. $13 \mathrm{hr}$ (from 24 to $72 \mathrm{hr}$ ). The $\mathrm{AUC}_{0-72}$ for i.v. was $20.8 \mu \mathrm{g} \mathrm{eq} . \mathrm{hr} / \mathrm{ml}$, giving a

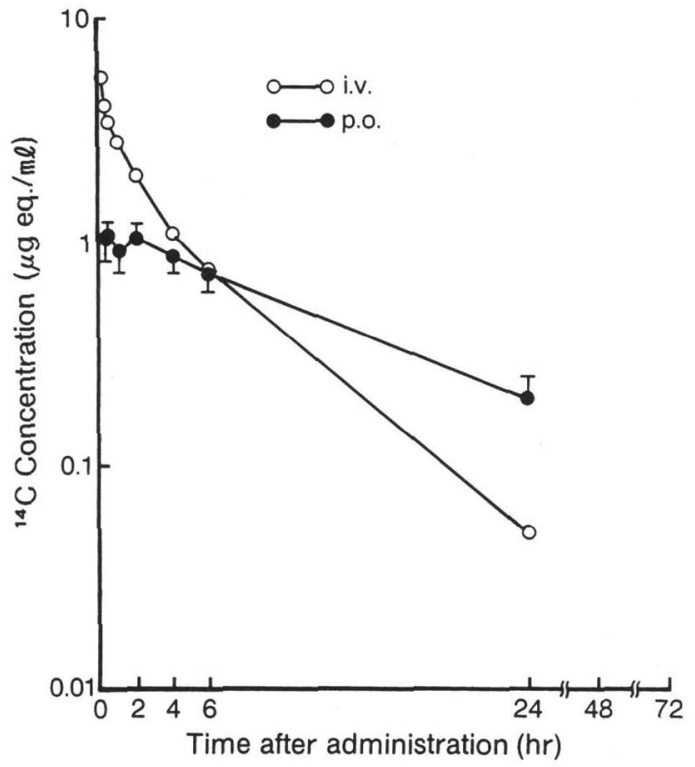

Fig. 2 Serum levels of radioactivity in rats after single oral or intravenous administration of ${ }^{14} \mathrm{C}-\mathrm{SM}-10888$ at dose of $5 \mathrm{mg} / \mathrm{kg}$

Each point represents the mean \pm S.E. of 5 rats.

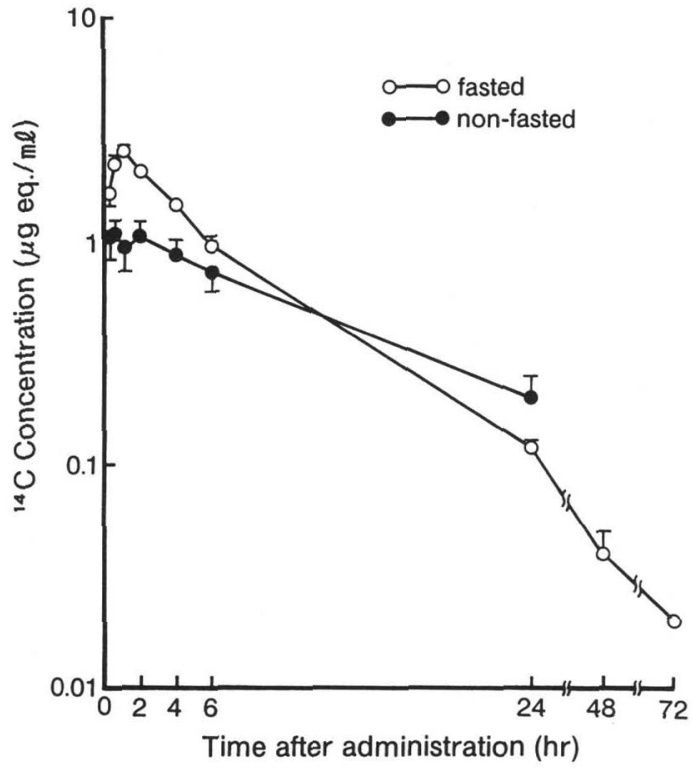

Fig. 3 Serum levels of radioactivity in rats after single oral administration of ${ }^{14} \mathrm{C}$ -SM-10888 at dose of $5 \mathrm{mg} / \mathrm{kg}$ under fasted or non-fasted conditions Each point represents the mean \pm S.E. of 5 rats. 


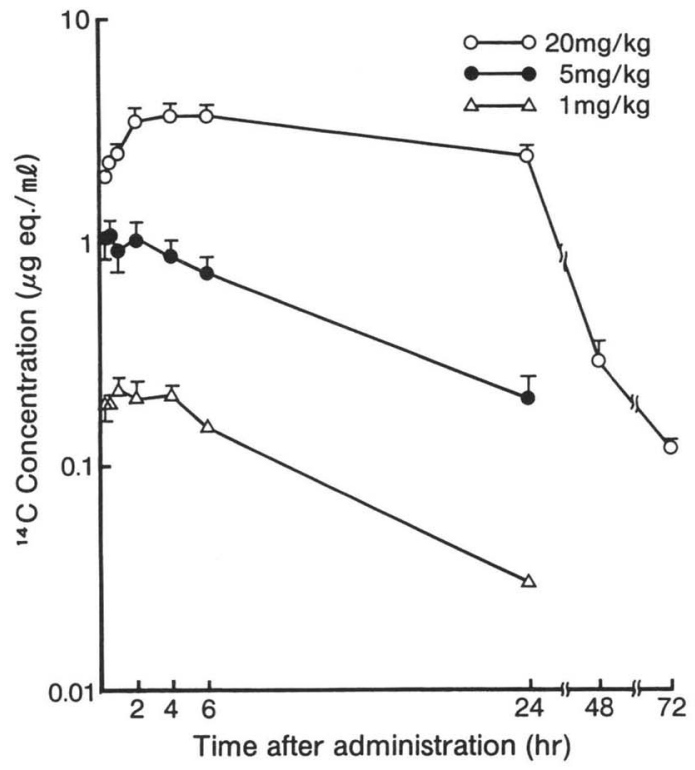

Fig. 4 Serum levels of radioactivity in rats after single oral administration of ${ }^{14} \mathrm{C}$ -SM-10888 at doses of 1,5 and $20 \mathrm{mg} /$ $\mathrm{kg}$

Each point represents the mean \pm S.E. of 5 rats.

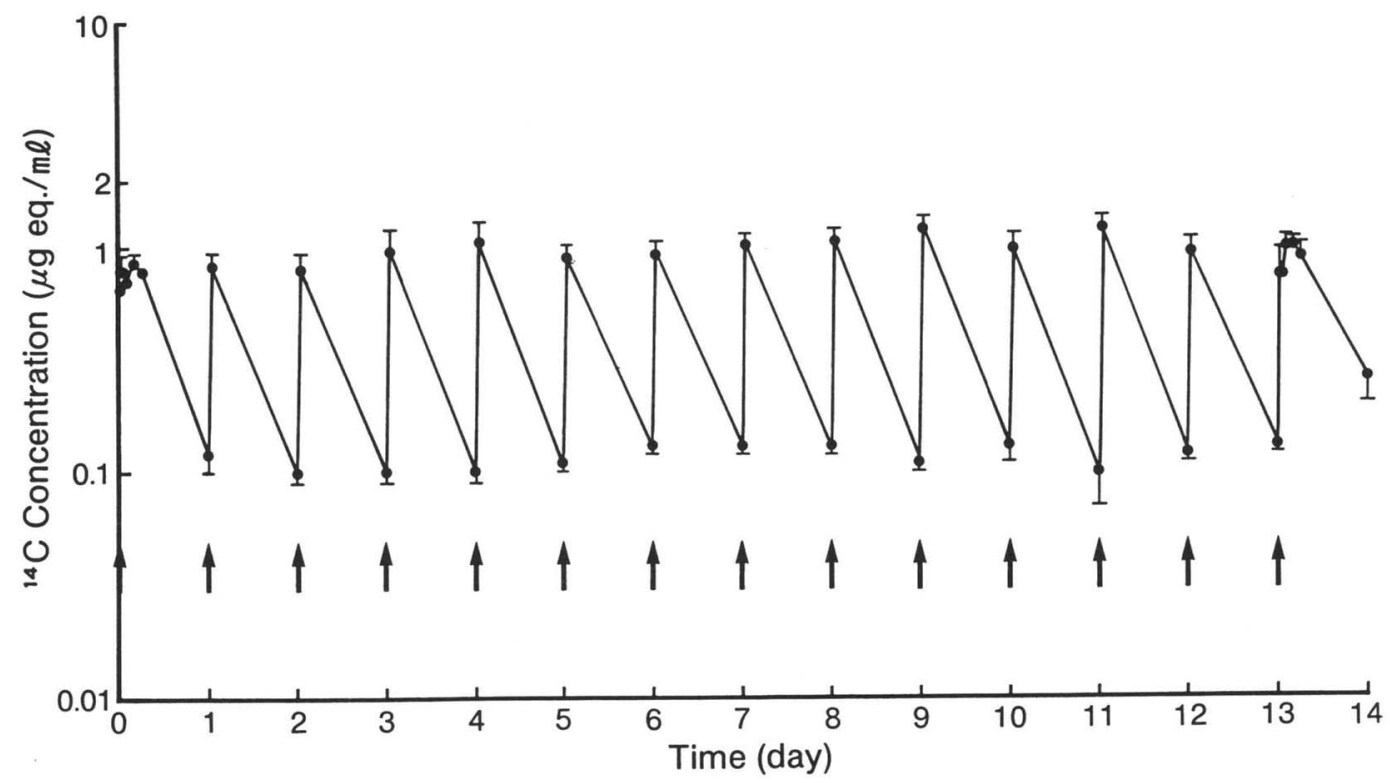

Fig. 5 Serum levels of radioactivity in rats during repeated daily administration of ${ }^{14} \mathrm{C}-\mathrm{SM}-10888$ at dose $5 \mathrm{mg} / \mathrm{kg} / \mathrm{day}$ Each point represents the mean \pm S.E. of 5 rats. 
Table I Tissue levels of radioactivity in rats after single oral administration of ${ }^{14} \mathrm{C}-\mathrm{SM}-10888$ at dose of $5 \mathrm{mg} / \mathrm{kg}$

\begin{tabular}{|c|c|c|c|}
\hline \multirow{2}{*}{ Tissue } & \multicolumn{3}{|c|}{ Concentration ( $\mu \mathrm{g}$ eq./g tisssue) } \\
\hline & $0.5 \mathrm{hr}^{\mathrm{a})}$ & $2 \mathrm{hr}$ & $24 \mathrm{hr}$ \\
\hline Cerebrum & $1.40 \pm 0.31^{\mathrm{b})}$ & $0.88 \pm 0.22$ & $<0.01$ \\
\hline Cerebellum & $1.17 \pm 0.25$ & $0.77 \pm 0.18$ & $<0.01$ \\
\hline Thyroid & $0.95 \pm 0.30$ & $0.53 \pm 0.17$ & $<0.08$ \\
\hline Salivary gland & $3.62 \pm 0.61$ & $4.34 \pm 0.96$ & $0.38 \pm 0.20$ \\
\hline Thymus & $1.17 \pm 0.32$ & $0.80 \pm 0.22$ & $<0.01$ \\
\hline Heart & $0.91 \pm 0.22$ & $0.59 \pm 0.12$ & $0.02 \pm 0.00$ \\
\hline Lung & $1.41 \pm 0.31$ & $1.00 \pm 0.28$ & $0.07 \pm 0.01$ \\
\hline Liver & $5.07 \pm 0.78$ & $3.12 \pm 0.74$ & $1.22 \pm 0.05$ \\
\hline Stomach & $8.16 \pm 2.18$ & $2.93 \pm 0.74$ & $0.03 \pm 0.01$ \\
\hline Large intestine & $1.25 \pm 0.37$ & $0.90 \pm 0.25$ & $0.52 \pm 0.09$ \\
\hline Small intestine & $7.17 \pm 1.59$ & 4. $18 \pm 1.22$ & $0.24 \pm 0.04$ \\
\hline Pancreas & $1.96 \pm 0.39$ & $1.20 \pm 0.31$ & $0.02 \pm 0.01$ \\
\hline Spleen & $2.14 \pm 0.48$ & $1.20 \pm 0.35$ & $0.01 \pm 0.00$ \\
\hline Adrenal & $3.57 \pm 0.35$ & $2.05 \pm 0.54$ & $0.10 \pm 0.01$ \\
\hline Kidney & $4.08 \pm 0.63$ & $3.02 \pm 0.96$ & $0.32 \pm 0.02$ \\
\hline Bladder & $2.63 \pm 0.11$ & $1.58 \pm 0.67$ & $0.13 \pm 0.04$ \\
\hline Testis & $1.05 \pm 0.29$ & $0.76 \pm 0.19$ & $<0.01$ \\
\hline Bone marrow & $1.78 \pm 0.48$ & $1.11 \pm 0.23$ & $<0.03$ \\
\hline Fat & $0.95 \pm 0.21$ & $0.57 \pm 0.29$ & $<0.02$ \\
\hline Muscle & $0.65 \pm 0.20$ & $0.46 \pm 0.12$ & $<0.01$ \\
\hline Skin & $0.82 \pm 0.23$ & $0.59 \pm 0.14$ & $0.08 \pm 0.01$ \\
\hline Blood & $0.61 \pm 0.16$ & $0.47 \pm 0.10$ & $0.04 \pm 0.00$ \\
\hline Serum & $0.82 \pm 0.21$ & $0.60 \pm 0.11$ & $0.04 \pm 0.01$ \\
\hline
\end{tabular}

a) Time after administration

b) Mean \pm S.E. of 3 rats

p.o./i.v. ratio of $89.4 \%$.

Serum levels of radioactivity after single oral administration of ${ }^{14} \mathrm{C}-\mathrm{SM}-10888(5 \mathrm{mg} /$ $\mathrm{kg}$ ) under non-fasted or fasted conditions are shown in Fig. 3. In rats fasted for $24 \mathrm{hr}$ before dosing, $\mathrm{C}_{\max }$ was $2.52 \mu \mathrm{g}$ eq. $/ \mathrm{ml}$ at $1 \mathrm{hr}$, and the level declined with a half-life of ca. $4 \mathrm{hr}$. The $\mathrm{AUC}_{0-72}$ value was $22.5 \mu \mathrm{g}$ eq. $\mathrm{hr} / \mathrm{m} l$.

Serum levels of radioactivity after single oral administrations of ${ }^{14} \mathrm{C}-\mathrm{SM}-10888$ at doses of 1,5 and $20 \mathrm{mg} / \mathrm{kg}$ are shown in Fig. 4 . In rats receiving $1 \mathrm{mg} / \mathrm{kg}, \mathrm{C}_{\max }$ was $0.21 \mu \mathrm{g}$ eq. $/ \mathrm{m} l$ at $1 \mathrm{hr}$, and the same level was maintained until the $4 \mathrm{hr}$ time point $(0.21 \mu \mathrm{g}$ eq./ $\mathrm{ml}$ ), followed by decline with a half-life of ca. $8 \mathrm{hr}$. The $\mathrm{AUC}_{0-72}$ was $3.2 \mu \mathrm{g} \mathrm{eq} \cdot \mathrm{hr} / \mathrm{m} l$. In rats receiving $20 \mathrm{mg} / \mathrm{kg}$, the serum level was $3.45 \mu \mathrm{g} \mathrm{eq.} / \mathrm{ml}$ at $2 \mathrm{hr}$, and this was maintained until $6 \mathrm{hr}(3.72 \mu \mathrm{g}$ eq. $/ \mathrm{ml})$, subsequently declining with a half life of ca. $11 \mathrm{hr}$. The $\mathrm{AUC}_{0-72}$ was $112 \mu \mathrm{g}$ eq. $\mathrm{hr} / \mathrm{ml}$.

\section{Repeated Dose}

Serum levels of radioactivity after repeated oral administration of ${ }^{14} \mathrm{C}-\mathrm{SM}-10888$ at dose of $5 \mathrm{mg} / \mathrm{kg} / \mathrm{day}$ are shown in Fig. 5. At day 1 , the serum level peaked at $30 \mathrm{~min}(0.81 \mu \mathrm{g}$ 


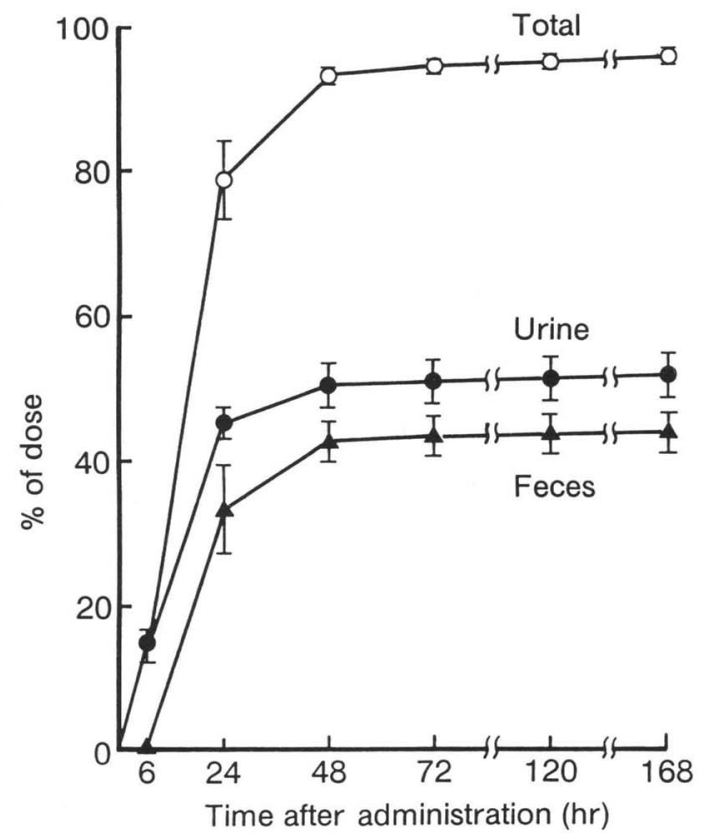

Fig. 6 Cumulative excretion of radioactivity into the urine and feces after single oral administration of ${ }^{14} \mathrm{C}-\mathrm{S} \mathrm{M}-10888$ at dose of $5 \mathrm{mg} / \mathrm{kg}$ to male rats Each point represents the mean \pm S.E. of 5 rats.

eq. $/ \mathrm{m} l$ ), declined slightly by $6 \mathrm{hr}$, and then fell to $0.12 \mu \mathrm{g}$ eq. $/ \mathrm{m} l$ by $24 \mathrm{hr}$. From days 2 to 13 , the serum levels at $30 \mathrm{~min}$ and $24 \mathrm{hr}$ after every daily dose were ca. $1.0 \mu \mathrm{g} \mathrm{eq.} / \mathrm{m} l$ and ca. $0.1 \mu \mathrm{g}$ eq. $/ \mathrm{ml}$, respectively, so that the pattern of changes in serum levels was quite steady throughout. At day 14, the level reached a maximum ( $\mathrm{C}_{\max }$ ) of $0.73 \mu \mathrm{g}$ eq./ $\mathrm{m} l$ at $30 \mathrm{~min}$, remained almost consistent until $6 \mathrm{hr}$, and then declined to $0.26 \mu \mathrm{g} \mathrm{eq} . / \mathrm{m} l$ at $24 \mathrm{hr}$.

\section{Biodistribution}

\section{Single Dose}

Table I summarizes the tissue levels of radioactivity at $30 \mathrm{~min}, 2$ and $24 \mathrm{hr}$ after single oral administration of $5 \mathrm{mg} / \mathrm{kg}$ of ${ }^{14} \mathrm{C}-\mathrm{SM}-10888$.

At $30 \mathrm{~min}$, in all tissues except the muscle, radioactivity level was equal to or exceeded the serum level $(0.82 \mu \mathrm{g}$ eq. $/ \mathrm{g})$. The gastrointestinal (GI) tract (e.g. the stomach $(8.16 \mu \mathrm{g}$ eq. $/ \mathrm{g})$ and the small intestine $(7.17 \mu \mathrm{g}$ eq./g) $)$ exhibited the highest level of radioactivity, followed by the liver $(5.07 \mu \mathrm{g}$ eq. $/ \mathrm{g})$, the kidney $(4.08 \mu \mathrm{g}$ eq. $/ \mathrm{g})$, the salivary gland $(3.62 \mu \mathrm{g}$ eq. $/ \mathrm{g})$ and the adrenal $(3.57 \mu \mathrm{g}$ eq./g). In the cerebrum, the target organ of SM-10888, the level (1. $40 \mu \mathrm{g}$ eq. $/ \mathrm{g})$ exceeded that in the serum $(0.82 \mu \mathrm{g}$ eq./g).

At $2 \mathrm{hr}$, the levels in most of the tissues except the salivary gland had decreased in comparison to those at $30 \mathrm{~min}$. The salivary gland showed the highest radioactivity, fol- 
Table II Tissue levels of radioactivity in rats after repeated daily administration of ${ }^{14} \mathrm{C}-\mathrm{SM}-10888$ at dose of $5 \mathrm{mg} / \mathrm{kg} / \mathrm{day}$

\begin{tabular}{|c|c|c|c|c|}
\hline \multirow{2}{*}{ Tissue } & \multicolumn{4}{|c|}{ Concentration ( $\mu \mathrm{g}$ eq./g tisssue) } \\
\hline & $0.5 \mathrm{hr}^{\mathrm{a})}$ & $2 \mathrm{hr}$ & $24 \mathrm{hr}$ & $72 \mathrm{hr}$ \\
\hline Cerebrum & $1.27 \pm 0.13^{\mathrm{b})}$ & $1.70 \pm 0.21$ & N.D.c) & N.D. ${ }^{c)}$ \\
\hline Cerebellum & $1.17 \pm 0.16$ & $1.41 \pm 0.18$ & N.D. ${ }^{c)}$ & N.D. ${ }^{c)}$ \\
\hline Pituitary & $2.32 \pm 0.28$ & $3.92 \pm 0.62$ & N.D. ${ }^{c)}$ & N.D. ${ }^{c)}$ \\
\hline Thyroid & $1.55 \pm 0.59$ & $1.76 \pm 0.32$ & N.D.c) & N.D. ${ }^{c)}$ \\
\hline Salivary gland & $4.37 \pm 0.65$ & 13. $24 \pm 1.66$ & $0.17 \pm 0.03$ & N.D. ${ }^{c)}$ \\
\hline Thymus & $1.13 \pm 0.11$ & $1.59 \pm 0.05$ & N.D. ${ }^{c)}$ & N.D. ${ }^{c)}$ \\
\hline Heart & $0.91 \pm 0.15$ & $1.37 \pm 0.13$ & $0.07 \pm 0.01$ & N.D.c) \\
\hline Lung & $1.58 \pm 0.15$ & $2.39 \pm 0.41$ & $0.25 \pm 0.04$ & $0.17 \pm 0.01$ \\
\hline Liver & $4.09 \pm 0.38$ & $12.60 \pm 0.89$ & $5.24 \pm 0.49$ & $2.17 \pm 0.05$ \\
\hline Stomach & $11.00 \pm 1.55$ & $6.05 \pm 1.25$ & $0.27 \pm 0.12$ & N.D. ${ }^{c)}$ \\
\hline Large intestine & $2.30 \pm 0.39$ & 3. $35 \pm 0.40$ & $0.67 \pm 0.22$ & N.D. ${ }^{c)}$ \\
\hline Small intestine & $10.59 \pm 3.93$ & $10.40 \pm 2.81$ & $0.88 \pm 0.27$ & N.D. ${ }^{c)}$ \\
\hline Pancreas & $1.50 \pm 0.39$ & $2.40 \pm 0.39$ & $0.05 \pm 0.01$ & N.D. ${ }^{c)}$ \\
\hline Spleen & $2.19 \pm 0.55$ & $3.20 \pm 0.43$ & $0.10 \pm 0.02$ & $0.10 \pm 0.01$ \\
\hline Adrenal & $3.03 \pm 0.72$ & 4. $85 \pm 0.67 *$ & $0.40 \pm 0.04$ & $0.20 \pm 0.01$ \\
\hline Kidney & $4.62 \pm 1.02$ & $6.90 \pm 0.74$ & $0.98 \pm 0.06$ & $0.38 \pm 0.02$ \\
\hline Bladder & 3. $26 \pm 1.68$ & $2.72 \pm 0.43$ & $0.29 \pm 0.05$ & $0.14 \pm 0.01$ \\
\hline Prostate & $1.66 \pm 0.68$ & $1.81 \pm 0.24$ & $0.08 \pm 0.01$ & N.D. ${ }^{c)}$ \\
\hline Testis & $0.76 \pm 0.20$ & $1.54 \pm 0.21$ & N.D. ${ }^{c)}$ & N.D. ${ }^{c)}$ \\
\hline Bone marrow & $1.85 \pm 0.57$ & $2.55 \pm 0.31$ & N.D. ${ }^{\text {c) }}$ & N.D. ${ }^{c)}$ \\
\hline Fat & $0.57 \pm 0.13$ & $1.48 \pm 0.26$ & N.D. ${ }^{c)}$ & N.D. ${ }^{c)}$ \\
\hline Muscle & $0.65 \pm 0.18$ & $0.98 \pm 0.15$ & N.D. ${ }^{c)}$ & N.D. ${ }^{c)}$ \\
\hline Skin & $1.07 \pm 0.12$ & $1.17 \pm 0.12$ & $0.23 \pm 0.06$ & $0.16 \pm 0.02$ \\
\hline Blood & $0.66 \pm 0.11$ & $0.96 \pm 0.09$ & $0.26 \pm 0.05$ & $0.22 \pm 0.02$ \\
\hline Serum & $0.64 \pm 0.15$ & $1.03 \pm 0.11$ & $0.12 \pm 0.02$ & N.D. ${ }^{c)}$ \\
\hline
\end{tabular}

a) Time after administration

b) Mean \pm S.E. of 5 rats (*: Mean \pm S.E. of 4 rats)

c) Not detected $(<0.05)$

lowed by the small intestine $(4.18 \mu \mathrm{g}$ eq./g), the liver $(3.12 \mu \mathrm{g}$ eq./g), the kidney $(3.02 \mu \mathrm{g}$ eq. $/ \mathrm{g})$, the stomach $(2.93 \mu \mathrm{g}$ eq. $/ \mathrm{g})$ and the adrenal $(2.05 \mu \mathrm{g}$ eq./g). At $24 \mathrm{hr}$, the levels in the liver $(1.22 \mu \mathrm{g} \mathrm{eq.} / \mathrm{g})$, the large intestine $(0.52 \mu \mathrm{g}$ eq. $/ \mathrm{g})$, the salivary gland $(0.38 \mu \mathrm{g}$ eq. $/ \mathrm{g})$ and the kidney $(0.32 \mu \mathrm{g}$ eq./g) were relatively higher than those in the rest of the tissues, which were similar to the serum level $(0.04 \mu \mathrm{g}$ eq. $/ \mathrm{g})$ or below the detection limit.

\section{Repeated Dose}

Rats received repeated oral doses $(5 \mathrm{mg} / \mathrm{kg} / \mathrm{day})$ of ${ }^{14} \mathrm{C}-\mathrm{SM}-10888$ for 14 days, and the tissue radioactivity levels at $30 \mathrm{~min}, 2,24$ and $72 \mathrm{hr}$ after the final dose are summarized in Table $\mathbb{I}$.

At $30 \mathrm{~min}$ after the final dose, radioactivity was distributed throughout the body, all tissues demonstrating levels almost identical to or exceeding the serum level $(0.64 \mu \mathrm{g}$ eq./g). In particular, the stomach $(11.00 \mu \mathrm{g}$ eq./g), the small intestine $(10.59 \mu \mathrm{g} \mathrm{eq./g})$ 


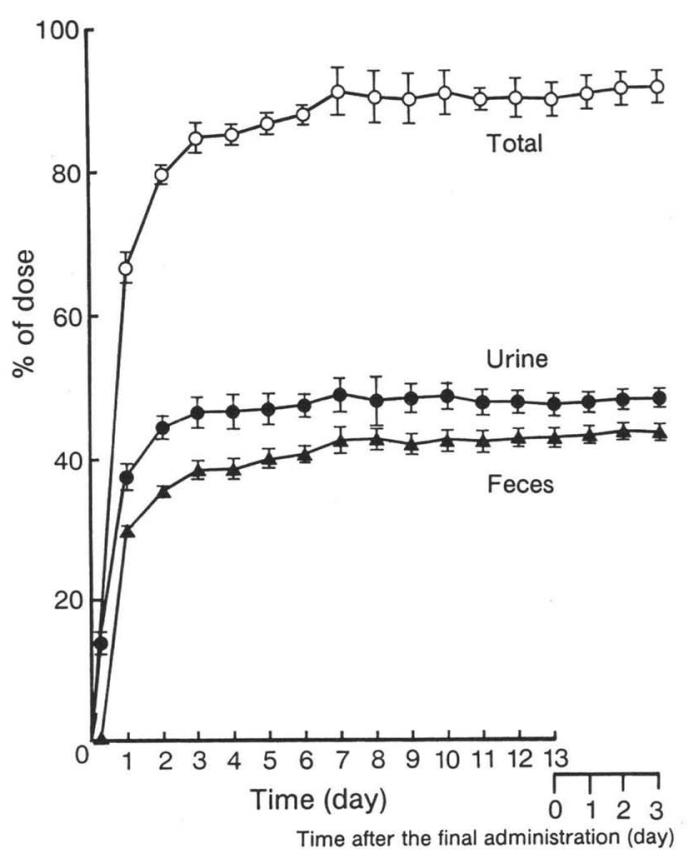

Fig. 7 Cumulative excretion of radioactivity during repeated daily administration of ${ }^{14} \mathrm{C}-\mathrm{SM}-10888$ at dose of $5 \mathrm{mg} / \mathrm{kg} / \mathrm{day}$ to male rats

Each point represents the mean \pm S.E. of 5 rats.

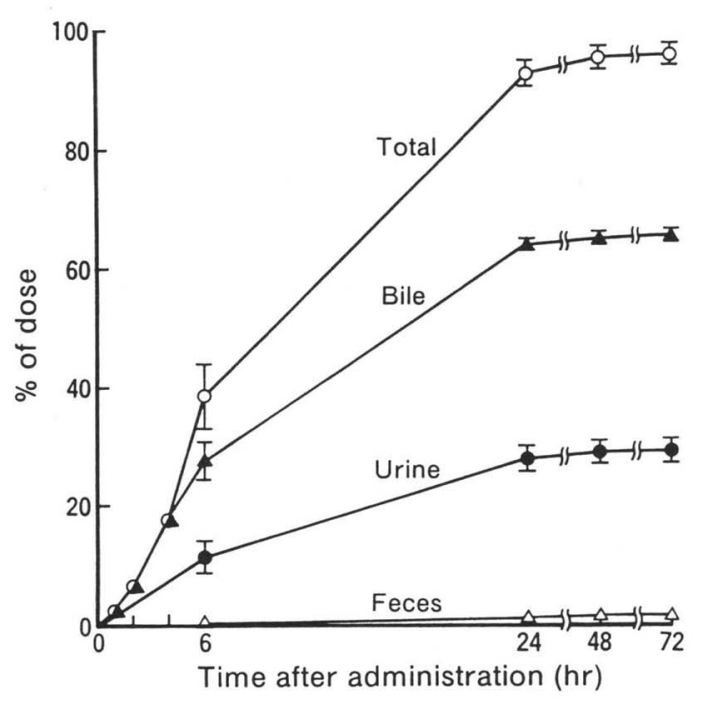

Fig. 8 Cumulative excretion of radioactivity into the bile, urine and feces after single oral administration of ${ }^{14} \mathrm{C}-\mathrm{SM}-10888$ at dose of $5 \mathrm{mg} / \mathrm{kg}$ to male rats Each point represents the mean \pm S.E. of 5 rats.

and the liver $(10.00 \mu \mathrm{g}$ eq./g) showed high levels, followed by the salivary gland $(6.87 \mu \mathrm{g}$ eq. $/ \mathrm{g})$, the kidney $(4.62 \mu \mathrm{g}$ eq. $/ \mathrm{g})$, the bladder $(3.26 \mu \mathrm{g}$ eq./g) and the adrenal $(3.03 \mu \mathrm{g}$ eq./g).

At $2 \mathrm{hr}$ after the final dose, as compared to the $30 \mathrm{~min}$ time point, the levels in all tissues but the stomach $(6.05 \mu \mathrm{g}$ eq./g) and the small intestine $(10.40 \mu \mathrm{g} \mathrm{eq.} / \mathrm{g})$ had increased along with the serum level $(1.03 \mu \mathrm{g}$ eq./g). The levels in the salivary gland $(13.24 \mu \mathrm{g}$ eq./ $\mathrm{g})$, the liver $(12.60 \mu \mathrm{g}$ eq. $/ \mathrm{g})$, the small intestine $(10.40 \mu \mathrm{g} \mathrm{eq.} / \mathrm{g})$, the kidney $(6.90 \mu \mathrm{g}$ eq./ $\mathrm{g})$, the stomach $(6.05 \mu \mathrm{g} \mathrm{eq} . / \mathrm{g})$ and the adrenal $(4.85 \mu \mathrm{g}$ eq./g) were especially elevated.

At $24 \mathrm{hr}$, the levels in all tissues were lower than those at $2 \mathrm{hr}$. That in the liver was still relatively high, but the concentration in the salivary gland was as low as the serum level $(0.12 \mu \mathrm{g} \mathrm{eq.} / \mathrm{g})$.

At $72 \mathrm{hr}$, except for the liver $(2.17 \mu \mathrm{g} \mathrm{eq.} / \mathrm{g})$ and the kidney $(0.38 \mu \mathrm{g}$ eq./g), the activities in most of tissues were around or below the detection limit.

\section{Excretion}

\section{Urine and Feces}

Cumulative excretion of radioactivity into the urine and feces after single oral administration of ${ }^{14} \mathrm{C}-\mathrm{SM}-10888$ at dose of $5 \mathrm{mg} / \mathrm{kg}$ are shown in Fig. 6. Excretion was almost completed at $24 \mathrm{hr}$ post dosing (urine ; $45.8 \%$, feces ; $33.2 \%$ ), and at $168 \mathrm{hr} 52.2 \%$ of dose 
had been excreted into the urine, and $44.2 \%$ into feces, i. e. total recovery was $96.4 \%$. No radioactivity was found in the expired air.

Cumulative excretion of radioactivity relative to cumulative dose during repeated daily oral administration of ${ }^{14} \mathrm{C}-\mathrm{SM}-10888$ at dose of $5 \mathrm{mg} / \mathrm{kg} / \mathrm{day}$ is shown in Fig. 7 . The excretion pattern remained essentially consistent from day 4 (urine; $38.3 \%$, feces ; $46.3 \%$, total $; 84.6 \%$ ) to day 14 (urine ; $42.8 \%$, feces ; $47.5 \%$, total ; $90.3 \%$ ). At $72 \mathrm{hr}$ after the final dose, total radioactivity excreted was $48.3 \%$ into the urine and $43.7 \%$ into the feces (total $92.0 \%$ ).

\section{Bile}

Bile-duct annulated rats received $5 \mathrm{mg} / \mathrm{kg}$ of ${ }^{14} \mathrm{C}-\mathrm{SM}-10888$ orally, and the cumulative excretion of radioactivity into bile, urine and feces is shown in Fig. 8. Excretion of radioactivity was almost complete at $24 \mathrm{hr}$ post dosing (bile; $63.8 \%$, urine; $27.9 \%$, feces ; $0.8 \%$ ). At $72 \mathrm{hr}$ recovery was $65.1 \%$ in bile, $29.1 \%$ in urine and $1.3 \%$ in feces.

\section{Discussion}

In order to clarify the disposition of SM-10888, ${ }^{14} \mathrm{C}$-labeled compound was given to rats, either orally or intravenously, and its absorption, distribution and excretion were investigated.

Since after oral dosing of ${ }^{14} \mathrm{C}-\mathrm{SM}-10888$ at $5 \mathrm{mg} / \mathrm{kg}$, the serum peak level of radioactivity was observed at $30 \mathrm{~min}$, and the AUC value was almost equal to that for intravenous application, rapid and high absorption of the compound from the GI tract is indicated.

To examine the effect of diet on absorption, serum levels of radioactivity were compared between fasted and non-fasted conditions. Although AUC did not markedly differ, $\mathrm{C}_{\max }$ in fasted rats was 2 -fold higher than in non-fasted animals, suggesting that the absorption from the GI tract was delayed by the presence of food.

When rats were administered 1,5 and $20 \mathrm{mg} / \mathrm{kg}$ of ${ }^{14} \mathrm{C}-\mathrm{SM}-10888, \mathrm{C}_{\max }$ and AUC increased in direct proportion to the dose level indicating no alteration in absorption characteristics within the range of doses tested.

Serum levels of radioactivity during repeated daily dosing were essentially identical to those after single dose and a steady state was maintained throughout two weeks of application. Repeated dosing would therefore be expected to exert minimal effects on disposition.

When ${ }^{14} \mathrm{C}-\mathrm{SM}-10888$ was given to rats orally, radioactivity was distributed throughout the body, including the cerebrum, the target organ of the drug, and then declined along with elimination from serum. No significant accumulations were evident and since SM-1 0888 is a lipophilic compound with a octanol/buffer $(\mathrm{pH} 7.4)$ partition coefficient $\left(\log \mathrm{P}^{*}=\right.$ $\left.2.23^{5}\right)$, this might result in high membrane permeability and a widespread distribution pattern. Although tissue levels of radioactivity after repeated dosing were 1 to 4 -fold higher than those after single dose, they also declined in line with reduction in the serum level.

Rat excreted almost all the radioactivity given orally into the urine and feces even with repeated dosing. The biliary excretion study confirmed that most of the radioactivity in 
the feces can be attributed to biliary excretion. The sum of the excretion rates into the bile and urine $(94 \%$ at $72 \mathrm{hr}$ ) also provides further support for a high absorption rate of this compound from the GI tract.

\section{Acknowled gements}

The authors would like to express their appreciation to Ms. Junko Kitada, Ms. Tomoko Kikuchi and Ms. Satomi Nishigaki who collaborated in this work.

\section{References}

1) Joseph T. Coyle, Donald L. Price and Mahlon R. Delong : Alzheimer's Disease : A Disorder of Cortical Cholinergic Innervation. Science, 219 : 1184-1190 (1983).

2) Robert E. Becker and Ezio Giacobini : Mechanism of Cholinesterase Inhibition in Senile Dementia of the Alzheimer Type : Clinical, Pharmacological, and Therapeutic Aspects. Drug Dev. Res., 12 : 163-195 (1988).

3) William K. Summers, John O. Viesselman, Gary M. Marsh and Kent Candelora : Use of THA in Treatment of Alzheimer-like dementia : Pilot Study in Twelve Patients. Biol. Psychiatry, 16 : 145-153 (1981).

4) William K. Summers, Lawrence V. Majovski, Gary M. Marsh, Kenneth Tschiki and Arthur Kling: Oral Tetrahydroaminoacridine in Long-term Treatment of Senile Dementia, Alzheimer Type. N. Engl. J. Med., 315: 1241-1245 (1986).

5) Kazuichi Natori, Yuko Okazaki, Tsunemasa Irie and Junki Katsube : Pharmacological and Biochemical Assessment of SM-10888, a Novel Cholinesterase Inhibitor. Japan. J. Pharmacol., 53 : 145-155 (1990).

6) Yuko Okazaki, Kazuichi Natori, Tsunemasa Irie and Junki Katsube : Effect of a Novel CNS-selective Cholinesterase Inhibitor, SM-10888, on Habituation and Passive Avoidance Responses in Mice. Japan. J. Phar macol., $53: 211-220$ (1990). 